\title{
AMICUS CURIAE BRIEF IN THE MATTER OF THE CO-PROSECUTORS' APPEAL OF THE CLOSING ORDER AGAINST KAING GUEK EAV "DUCH" DATED 8 AUGUST $2008^{* *}$
}

Before the Pre-trial Chamber Extraordinary Chambers in the Courts of Cambodia. Case File No.: 001/18-07-2007-ECCC/OCIJ ( PTC 02)

\section{EXECUTIVE SUMMARY}

1. From a conceptual perspective, (infra 3.2) the JCE doctrine serves to impute certain criminal acts or results to persons for their participation in a collective ("joint") criminal enterprise. The "criminal enterprise" is defined by a common - explicit or tacit - agreement or understanding to commit certain criminal acts for an ultimate criminal objective or goal. The underlying rationale of a JCE, its core feature, is the combined, associated or common criminal purpose ${ }^{1}$ of the participants in the enterprise. The common purpose is the collective element of the JCE doctrine which links the members among themselves ${ }^{2}$ and turns it into a theory of collective responsibility.

2. JCE I resembles traditional co-perpetration, since the participants act on the basis of a common plan ("common design" or "common enterprise"). If one construes JCE I as containing objective and subjective elements, in the sense of the functional control concept, it

* Professor, Institute for Criminal Law and Justice, Department of Foreign and International Criminal Law, Georg-August Universität Göttingen, Judge State Court Göttingen. I am grateful to my research assistant Lydia Löhner for her help in preparing this amicus curiae and to Timothy Campbell for language revision.

**Apart from a few updates, the Brief is published as submitted by the author.

${ }^{1}$ J. Vogel, "Individuelle Verantwortlichkeit im Völkerstrafrecht", (2002) 114 Zeitschrift für die gesamte Strafrechtswissenschaft (ZStW) 403, at 421; see also E. van Sliedregt, "Joint Criminal Enterprise as a Pathway to Convicting Individuals for Genocide", (2007) 5 Journal of International Criminal Justice (JICJ) 184, at 200, 203.

${ }^{2}$ Cf. H. van der Wilt, "Joint Criminal Enterprise", (2007) 5 JICJ 91, at 99 et seq., 107. However, an additional agreement between the superior and the direct perpetrators is not necessary, see infra note 9 . 
can be considered as a form of co-perpetration within the meaning of Art. 25 (3) (a) alt. 2 ICC Statute and, as such, as a form of commission pursuant to Art. 7 (1) ICTY/Art. 6 (1) ICTR Statutes. JCE II can be treated as a sub-category of JCE I if it is interpreted narrowly. In a broad sense of an extension of liability, JCE II rather resembles JCE III. JCE III cannot be considered as a form of co-perpetration, but only as a form of aiding and abetting the criminal enterprise. It is an autonomous concept of imputation which does not constitute commission in the sense of Art. 7 (1) ICTY/Art. 6 (1) ICTR Statutes. In fact, JCE III demonstrates most clearly the JCE doctrine's similarity to classical conspiracy liability, as it even holds a participant in a criminal enterprise responsible for the crimes of other participants not explicitly agreed upon beforehand, provided that they are foreseeable. Thus, the liability is essentially based on the membership in the group pursuing the JCE and, as such, conflicts with the principle of culpability.

3. For the application of the JCE doctrine before the ECCC (Part IV of this brief) this means that one must distinguish between the three forms of JCE. The test to be applied follows from the principle of legality recognized in International Criminal and the ECCC Law (4.1). Per the wording of Art. 29 (1) ECCC Law, JCE I can be considered "commission," as it resembles co-perpetration in a traditional sense, JCE III only entails accomplice liability and as such does not constitute commission, and with JCE II, it depends if it is understood in the sense of JCE I or JCE III (4.2).

4. As to the customary law status of JCE, again a differentiation is necessary (4.3). Although JCE I liability was recognized by post World War II case law and, therefore, also existed at the time of the commission of the crimes in question in Cambodia, this is not the case with regards to JCE III and JCE II, unless it is interpreted in the narrow sense as a sub-category of JCE I. This is confirmed by Cambodian Law applicable at the time of commission (4.4): only JCE I existed unambiguously, while JCE III was clearly not encompassed by the Code of 1956; as to JCE II, it is only covered if it is construed as a sub-category of JCE I. Consequently, only JCE I and JCE II (in a narrow sense) are applicable law for the case at hand.

\section{PRELIMINARY REMARKS}

The author has been asked to prepare an amicus curiae brief on the following two issues: 
(1) The development of the theory of JCE and the evolution of the definition of this mode of liability, with particular reference to the time period 1975-1979;

(2) The application of JCE as a mode of liability before the ECCC, taking into account the fact that the crimes were committed during the period of 1975-1979.

I deal with these issues by dividing my submission into two parts. In the first (general) part (infra III), drawing on earlier works, ${ }^{3}$ I will explain JCE by referring to modern case law (3.1) and its purpose and conceptual ("dogmatic") structure (3.2). I will then compare JCE to the traditional forms of participation in order to more exactly classify the three forms of JCE identified by the case law and prepare the ground for the second (special) part (IV) In this part, I will examine if JCE is, first, applicable under the ECCC law and/or, second, can be applied retroactively to the crimes committed during 1975-1979.

\section{GENERAL CONSIDERATIONS}

\subsection{JCE in Modern Case Law}

The JCE doctrine ${ }^{4}$ can be traced back to the Tadic Appeals Chamber Judgment. ${ }^{5}$ The Chamber looked for a theory of participation in international crimes which takes sufficiently into account the collective, widespread and systematic context of the commission of such crimes and, thus, helps to overcome the typical problems of proof with regard to the - sometimes hardly visible - contributions of individual participants. The Chamber correctly acknowledged that "most of (...) these crimes (...) constitute manifestations of collective criminality: the crimes are often carried out by groups or individuals

\footnotetext{
${ }^{3}$ I rely in this part especially on my paper "Joint criminal enterprise and command responsibility", (2007) 5 JICJ 159.

${ }^{4}$ According to A.M. Danner and J.S. Martinez, "Guilty Associations: Joint Criminal Enterprise, Command Responsibility, and the Development of International Criminal Law," (2005) 93 California Law Review 75, at 107, 64\% of the indictments submitted to the ICTY between 25 June, 2001 and 1 January, 2004 relied on this doctrine. On the importance of JCE, also see N. Piacente, "Importance of the JCE Doctrine for the ICTY Prosecutorial Policy," (2004) 2 JICJ 446, at 448; M. Osiel, "The Banality of the Good: Aligning Incentives against Mass Atrocity," (2005) 105 Columbia Law Review 1751, at 1783.

5 Prosecutor v. Tadić, Judgment, Case No. IT-94-1, ICTY Appeals Chamber, 15 July, 1999, § 185 et seq.
} 
acting in pursuance of a common criminal design". ${ }^{6}$ The Chamber distinguished, relying on post World War II case law (on this reliance in more detail infra 4.2) three categories of collective criminality ${ }^{7}$ :

(1) the basic form where the participants act on the basis of a "common design" or "common enterprise" and with a common "intention" (hereinafter "JCE I");

(2) the systemic form, i.e., the so-called concentration camp cases where crimes are committed by members of military or administrative units such as those running concentration or detention camps on the basis of a common plan ("common purpose") (hereinafter "JCE II");

(3) the so called "extended" joint enterprise where one of the coperpetrators actually engages in acts going beyond the common plan, but his or her acts still constitute a "natural and foreseeable consequence" of the realization of the plan (hereinafter "JCE III").

The objective elements of JCE liability are threefold:

(1) a plurality of persons;

(2) the existence of a common plan, design or purpose; and

(3) the participation of the accused in the JCE by any "form of assistance in, or contribution to, the execution of the common purpose".

Subsequently, the Appeals Chamber tried to give the objective elements of JCE a more precise meaning by developing the following

${ }^{6}$ Tadić Appeals Judgment, supra note 5, § 191; Prosecutor v. Krajisnik, Judgment, Case No. IT-00-39-T, ICTY Trial Chamber, 27 September, 2006, § 876: "JCE is well suited to cases such as the present one, in which numerous persons are all said to be concerned with the commission of a large number of crimes." Critically about the JCE's ability to deal with macrocriminality, see: van der Wilt, supra note 2, at 101: "[...] the doctrine does not tally with the reality of modern bureaucracies that engage in systematic mass crime." For another view: K. Gustafson, "The Requirement of an 'Express Agreement' for Joint Criminal Enterprise Liability," (2007) 5 JICJ 134, at 149 , argues that JCE "allows for, and even requires, a broader approach in which the contributions of that individual are analyzed in the context of criminal conduct carried out jointly by a group of actors." (at 139). In the same vein: A. Cassese, "The Proper Limits of Individual Responsibility under the Doctrine of Joint Criminal Enterprise," (2007) 5 JICJ 109, at 110-111.

${ }^{7}$ Cassese, supra note 6 , at 111 et seq. calls these three forms "liability for a common intentional purpose," "liability for participation in an institutionalized common criminal plan" and "incidental criminal liability based on foresight and voluntary assumption of risk." 
criteria $^{8}$ : as to the plurality of persons, it is not necessary to identify each member by name; as to the common purpose, the prosecutor must determine precisely the objective, the temporal, geographic etc. scope and that the purpose is effectively common for all members of the $\mathrm{JCE}^{9}$; last but not least the prosecutor must prove a significant contribution ${ }^{10}$ of the accused in the execution of the purpose of the JCE. In addition, the Chamber made clear that the direct perpetrators do not necessarily have to belong to the JCE (I), i.e., it is possible for the superiors (e.g., the leadership of a totalitarian regime) to form a JCE among themselves and use direct perpetrators who do not belong to this JCE (although they may eventually belong to a parallel JCE) for the execution of their objectives. In order to impute in this case the crimes of the "external" direct perpetrators to the members of the JCE, it is necessary to prove at least the existence of a nexus between the direct perpetrators and their acts with at least one member of the JCE and that this member acted by virtue of a common agreement between

${ }^{8}$ Prosecutor v. Brdanin, Judgment, Case No. IT-99-36-A, ICTY Appeals Chamber, 3 April, 2007, § 430. See also Prosecutor v. Martić, Judgment, Case No. IT-9511-T, ICTY Trial Chamber, 12 June, 2007, $\S$ 435-40, recently approved by the Appeals Chamber, Judgment, Case No. IT-95-11-A, ICTY Appeals Chamber, 8 October, 2008, §§ 79-85; Prosecutor v. Krajišnik, Judgment, Case No. IT-00-39-A, ICTY Appeals Chamber, 17 March, 2009, §§ 156-157.

${ }^{9}$ An additional agreement (between the superior and the direct perpetrator) is, in addition to the common purpose, not necessary, see: Brdanin Appeals Judgment, supra note $8, \S 418$ : "In cases where the principal perpetrator shares that common criminal purpose of the JCE or, in other words, is a member of the JCE, and commits a crime in furtherance of the JCE, it is superfluous to require an additional agreement between that person and the accused to commit that particular crime." Concurring: Prosecutor v. Limaj et al., Judgment, Case No. IT-03-66-A, ICTY Appeals Chamber, 27 September, 2007, § 104; Prosecutor v. Mrksić, Judgment, Case No. IT-95-13/1-T, ICTY Trial Chamber, 27 September, 2007, § 545; Prosecutor $v$. Boskoski, Judgment, Case No. IT-04-82-T, ICTY Trial Chamber, 10 July, 2008, § 395. In the same vein: Gustafson, supra note 6, at 147 et seq., criticizing the sentence of the Trial Chamber. Defending its position: Cassese, supra note 6, at 125-126; van Sliedregt, supra note 1 , at 201. In any case, there seems to be consensus as to the requirement of a common purpose or plan as the basis of attribution, while an additional agreement to commit specific crimes is not necessary (see also: van Sliedregt, supra note 1, at 200). See also: Krajisnik Trial Judgment, supra note $6, \S$ 884, 1120 requiring "joint action" in the sense of interaction or co-ordination; concurring: A. Zahar and G. Sluiter, International Criminal Law (2008), 255-256.

${ }^{10}$ Brdanin Appeals Judgment, supra note $8, \S 430$; Mrksić Trial Judgment, supra note 9, § 545; Boskoski Trial Judgment, supra note 9, § 395. Critical about this requirement: Gustafson, supra note 6 , at 141 ; in favour: Cassese, supra note 6 , at 128, 133; K. Hamdorf, "The Concept of a Joint Criminal Enterprise and Domestic Modes of Liability for Parties to a Crime," (2007) 5 JICJ 208, at 225. 
all the members of the JCE. ${ }^{11}$ In this way, the Chamber creates a form of indirect co-perpetration (or co-perpetration by way of others) of the members of the JCE with regard to the direct perpetrators who, however, are not mere instruments of the superiors. ${ }^{12}$ While these requirements equally apply to JCE I, II and III, the subjective requirements vary according to the category of $\mathrm{JCE}^{13}$ : JCE I requires the shared intent of the (co-) perpetrators; JCE II demands personal knowledge of the system of ill-treatment; JCE III requires an intention (i) to participate in the criminal purpose and further this purpose, on the one hand, and (ii) to contribute to the commission of a crime by a group, on the other. Responsibility for a crime which was not part of the common purpose arises if the commission of this crime was foreseeable and the accused (willingly) took that risk.

The subsequent ICTY/ICTR case law basically followed the Tadic ruling. ${ }^{14}$ As to the new mixed tribunals, only the East Timorese Special

${ }^{11}$ Brdanin Appeals Judgment, supra note 8, $\S 410$ et seq., 430; Mrksić Trial Judgment, supra note 9, § 547; Boskoski Trial Judgment, supra note 9, § 397; Prosecutor v. Zigiranyirazo, Judgment Case No. ICTR-01-73-T, ICTR Trial Chamber, 18 December, 2008, § 384; Prosecutor v. Milutinović et al., Judgment, Case No. IT05-87-T, ICTY Trial Chamber, 26 February, 2009, §§ 98-99; Krajišnik Appeals Judgment, supra note $8, \S 235$; In the same vein: Gustafson, supra note 6, at 147 et seq., 154 et seq.

${ }^{12}$ For this reason it is puzzling if the prosecutor refers to the direct perpetrators as "tools" who are used by the members of the JCE (cf. Brdanin Appeals Judgment, supra note $8, \S 412$ ).

${ }^{13}$ Cf. Tadić Appeals Judgment, supra note 5, $\S 196,202,220,228$; concurring: Prosecutor v. Krnojelac, Judgment, Case No. IT-97-25-A, ICTY Appeals Chamber, 17 September, 2003, § 32; Prosecutor v. Vasiljević, Judgment, Case No. IT-98-32-A, ICTY Appeals Chamber, 25 February, 2004, § 101; Prosecutor v. Ntakirutimana \& Ntakirutimana, Judgment, Case No. ICTR-96-10; ICTR-96-17, ICTR Appeals Chamber, 13 December, 2004, § 467 with further references; Prosecutor v. Stakić, Judgment, Case No. IT-97-24-A, ICTY Appeals Chamber, 22 March, 2006, §§ 65, 101; Mrksić Trial Judgment, supra note 9, § 545; Martić Trial Judgment, supra note 8, § 439; Martić Appeals Judgment, supra note $8, \S 83$; Boskoski Trial Judgment, supra note 9, § 396; Zigiranyirazo Trial Judgment, supra note $11, \S 385$; Milutinović Trial Judgment, supra note $11, \S \S 107-112$.

${ }^{14}$ See e.g. Prosecutor v. Furundžija, Judgment, Case No. IT-95-17/1, ICTY Appeals Chamber, 21 July, 2000, $\S \$ 117$ et seq.; Krnojelac Appeals Judgment, supra note 13, 29 et seq.; Vasiljević Appeals Judgment, supra note 13, $\S 95$ et seq.; Stakić Appeals Judgment, supra note 13, §§ 64, 65; Mrksić Trial Judgment, supra note 9, $\S 545$ et seq.; Prosecutor v. Haradinaj, Balaj, Brahimaj, Judgment, Case No. IT-04-84-T, ICTY Trial Chamber, 3 April, 2008, §§ 135 et seq.; Milutinović Trial Judgment, supra note 11, §§ 95 et seq. For the ICTR see: Ntakirutimana Appeals Judgment, supra note 13, $\S \$ 462$ et seq.; Prosecutor v. Simba, Judgment and Sentence, Case No. ICTR-01-76, ICTR Trial 
Panel for Serious Crimes ${ }^{15}$ has so far applied the JCE doctrine. ${ }^{16}$ The Pre-Trial Chamber of the International Criminal Court ("ICC") in the Lubanga and in the Katanga \& Ngudjolo cases ${ }^{17}$ has dissociated itself from the JCE doctrine, at least as far as it goes beyond mere co-perpetration in the sense of Art. 25 (3) (a) ICC Statute, i.e., in its systemic

Footnote 14 continued

Chamber, 13 December, 2005, $\S \S 386-388$; confirmed by the Appeals Chamber, Judgment, Case No. ICTR-01-76-A, ICTR Appeals Chamber, 27 November, 2007, $\S \S 250$ et seq.; Prosecutor v. Nchamihigo, Judgment, Case No. ICTR-01-63-T, ICTR Trial Chamber, 12 November, 2008, § 327; Zigiranyirazo Trial Judgment, supra note 11, §§ 383 et seq.; Prosecutor v. Rukundo, Judgment, Case No. ICTR-2001-70-T, ICTR Trial Chamber, 27 February, 2009, §§ 24 et seq.

${ }^{15}$ See Prosecutor v. Perreira, Judgment, Case No. 34/2003, Special Panel for Serious Crimes, 27 April, 2005, at 19-20, (www.jsmp.minihub.org/Court\%20Monitoring/ spsccaseinformation2003.htm [visited 16 October, 2008]). Concurring also: Ibid., Separate Opinion of Judge Phillip Rapoza, at 4-5, §§ 17-18, 25. See also: Prosecutor v. Domingos de Deus, Judgment, Case No. 2a/2004, Special Panel for Serious Crimes, 12 April, 2005, at 13 (www.jsmp.minihub.org/Court\%20Monitoring/spsccase information2004.htm [visited 15 October, 2008]); Prosecutor v. Cardoso, Judgment, Case No. 04/2001, Special Panel for Serious Crimes, 5 April, 2003, §§ 367 et seq. (www.jsmp.minihub.org/Court\%20Monitoring/spsccaseinformation2001.htm [visited 16 October, 2008]). Meanwhile, also the Special Court for Sierra Leone has adopted the JCE doctrine, Prosecutor v. Sesay, Judgment, Case No. SCSL-04-15-T, SCSL Trial Chamber, 2 March, 2009, $\S \S 252$ et seq.

${ }^{16}$ As to the indictments before the Sierra Leone Special Court invoking JCE III, see: Danner and Martinez, supra note 4, at 155-156.

${ }^{17}$ Prosecutor v. Thomas Lubanga Dyilo, Decision on the confirmation of charges, ICC-01/04-01/06-803-tEN, ICC Pre-Trial Chamber I, Situation in the Democratic Rep. of Congo, 29 January, 2007, §§ 326-329; Prosecutor v. Germain Katanga and Mathieu Ngudjolo Chui, Decision on the Confirmation of Charges, ICC-01/04-01/07717, ICC Pre Trial Chamber I, Situation in the Democratic Rep. of Congo, 30 September, 2008, $\S \S 480$ et seq. The Chamber associates the JCE doctrine with the subjective approach in the law of co-perpetration, i.e., the determination of co-perpetration essentially by taking recourse to the intention or will of the parties. It then dismisses this approach and, therefore, implicitly also the JCE doctrine. See thereto F. Jessberger/J. Geneuss, "On the Application of a Theory of Indirect Perpetration in Al Bashir. German Doctrine at The Hague?", (2008) 6 JICL 853, at 858. Nevertheless, A. T. Cayley, "The Prosecutor's Strategy in Seeking the Arrest of Sudanese President Al Bashir on Charges of Genocide", (2008) 6 JICL 829, at 838-839 argues for the application of the JCE doctrine in the proceedings against Al Bashir. 
(JCE II) and extended forms (JCE III). It remains to be seen if these first decisions herald the end of JCE at the ICC. ${ }^{18}$

\subsection{Purpose and Conceptual ("dogmatic") Structure}

The JCE doctrine serves to impute certain criminal acts or results to persons for their participation in a collective ("joint") criminal enterprise. The "criminal enterprise" is defined by a common - explicit or tacit - agreement or understanding to commit certain criminal acts for an ultimate criminal objective or goal, e.g. in the case of a genocidal enterprise, the ultimate destruction of the targeted group. Such a global or broad enterprise normally consists of various smaller ("subsidiary") sub-enterprises, ${ }^{19}$ e.g. the running of concentration or prison camps for the members of the targeted group, the locally or regionally organized persecution of members of the group, etc. ${ }^{20}$ The participants in the enterprise are bound together by their common will to achieve the ultimate goal by all means necessary, i.e. by the crimes that must be committed on the road to the ultimate criminal goal. The underlying rationale of a JCE, its core feature, is the combined, associated or common criminal purpose $^{21}$ of the participants in the enterprise. The common purpose is the collective element of the JCE doctrine which links the members among themselves ${ }^{22}$ and turns it into a theory of collective responsibility based on an institutional-participatory ${ }^{23}$ or a systemic ${ }^{24}$

${ }^{18}$ See also T. Weigend, "Intent, Mistake of Law, and Co-perpetration in the Lubanga Decision on Confirmation of Charges," (2008) 6 JICJ 471, at 478; Jessberger/Geneuss, supra note 17 , at 867 .

${ }^{19}$ Cf. Prosecutor v. Kvočka, Judgment, Case No. IT-98-30/1-T, ICTY Trial Chamber, 2 November, 2001, § 307.

${ }^{20}$ Critical on such broad interpretations: Danner and Martinez, supra note 4, at 135 et seq.; critical also: Osiel, supra note 4, at 1796 et seq., 1802 et seq. and id., "Modes of Participation in Mass Atrocity," (2005) 39 Cornell International Law Journal 793, at 799-800.

${ }^{21}$ Vogel, supra note 1, at 421; see also: van Sliedregt, supra note 1, at 200, 203.

${ }^{22}$ Cf. van der Wilt, supra note 2, at 99 et seq., 107. Yet, an additional agreement between the superior and the direct perpetrators is not necessary, see supra note 9 .

${ }^{23}$ Cf. H. Jung, "Begründung, Abbruch und Modifikation der Zurechnung beim Verhalten mehrerer", in A. Eser, B. Huber, K. Cornils (Eds.), Einzelverantwortung und Mitverantwortung im Strafrecht (1998), 175 at 183 et seq.; in favour of a "form of criminal participation:" van Sliedregt, supra note 1, at 201-202.

${ }^{24} \mathrm{Cf}$. Vogel, supra note 1, at 420 et seq.; see for a systemic imputation ("global approach") also: Piacente, supra note 4 , at 446 et seq. 
model of imputation or attribution. Insofar, the doctrine resembles the law of conspiracy ${ }^{25}$ and the membership or organizational liability as applied in Nuremberg. ${ }^{26}$

This general explanation needs further differentiation with regards to the three forms of JCE identified by the case law. This, in turn, presupposes an analysis of JCE with regard to the traditional law of participation.

\subsection{JCE I and Traditional Forms of Participation}

While traditional (national) doctrine cannot simply be transposed without further ado to international criminal law (ICL), since it focuses on the role and contribution of perpetrators in an individual instead of a collective or systemic setting, it still helps explain and systematize the forms of imputation and participation in ICL. It also provides for forms of collective participation as the examples of conspiracy and membership liability show. In fact, the JCE doctrine can be traced back to the English common purpose theory, ${ }^{27}$ i.e., a kind of subjective co-perpetration. From the perspective of a differentiating concept of participation, the delimitation of co-perpetration and mere complicity (aiding and abetting) is crucial and runs along

${ }^{25}$ Cf. G.P. Fletcher and J.D. Ohlin, "Reclaiming Fundamental Principle of Criminal Law in the Darfur Case", (2005) 3 JICJ 539, at 548; E. van Sliedregt, The Criminal Responsibility of Individuals for Violations of International Humanitarian Law (2003), 355; S. Powles, "Joint Criminal Enterprise: Criminal Liability by Prosecutorial Ingenuity and Judicial Creativity?", (2004) 2 JICJ 606, at 613; Piacente, supra note 4, at 451; Danner and Martinez, supra note 4, at 118-119; Osiel, supra note 4, at 1785, 1791-1792; van der Wilt, supra note 2, at 96. For a different view, see: van Sliedregt, supra note 1, at 201.

${ }^{26}$ See for a detailed analysis: van Sliedregt, supra note 25 , at 17 et seq., 20 et seq., 352 et seq. (regarding JCE as "membership responsibility" distinguishing between "institutionalised" and "collateral" membership responsibility); Danner and Martinez, supra note 4, at 113-114; S. Römer, Mitglieder verbrecherischer Organisationen nach 1945 (2005), at 28 et seq.; Osiel, supra note 4, at 1799-1800. Yet, Piacente, supra note 4 , at 452, argues in favour of the Nuremberg "judicial recognition of the common illegal purpose."

${ }^{27}$ It goes back to the fourteenth century when liability was based on a "common consent" (see A.T.H. Smith, A Modern Treatise on the Law of Criminal Complicity [1991], at 209, note 1). Later, in the seventeenth century, the private law concept of "acting in concert" or "conspiracy" was used to punish specific agreements to commit unlawful acts (see Ordinance of Conspirators, 1305, 33 Edw. 1; generally Note [1959] 920, 922-923). See also more recently: V. Haan, Joint Criminal Enterprise. Die Entwicklung einer mittäterschaftlichen Zurechnungsfigur im Völkerstrafrecht (2008), 198. 
the lines of the degree of the (objective) participation in the (subjective) criminal plan. In other words, with a decreasing degree of participation, co-perpetration comes closer to mere aiding and abetting, and the delimitation between them becomes blurred.

While the Tadic Appeals Chamber did not clarify whether the JCE doctrine belongs to the traditional law of participation or constitutes a new and autonomous form of criminal imputation, some judgments have at least acknowledged the problem of the correct form of participation and opted for a subjective solution. In Kvock $a$ et al., a Trial Chamber, in this respect critical of the Tadić Appeals Judgment, considered that aiding and abetting in its traditional form may also be applied in relation to a JCE, and the difference between co-perpetration and aiding and abetting is a subjective one: If "the participant shares the intent of the criminal enterprise," he is a co-perpetrator, if he "only" possesses knowledge, an aider and abettor to the JCE. ${ }^{28} \mathrm{~A}$ few paragraphs later, however, the Chamber recognizes that there is also an objective side to the distinction: an aider or abettor may graduate to a co-perpetrator if his participation "lasts for an extensive period or (he) becomes more involved;", kind of participation depends on "the position in the organizational hierarchy and the degree of (...) participation." 30 A co-perpetrator performs a more active role, "either through committing violations of human rights in his own right or through the pervasiveness of his influence;" an aider and abettor plays a more limited role, basically doing his job discreetly. ${ }^{31}$ In any case, "[L]iability for foreseeable crimes flows to aiders and abettors as well as co-perpetrators" of the JCE. ${ }^{32}$ The Appeals Chamber does not see an objective difference between aiding and abetting a single crime or a JCE. In both cases, a "substantial contribution" is necessary. ${ }^{33}$ The difference is a subjective one: where the accused knows he is aiding and abetting a single crime, he is liable with regard to that crime, even if the principal perpetrator belongs to a JCE; where the accused knows that he helps a group crime, part of a JCE, and shares the group's intent, he is liable for

\footnotetext{
${ }^{28}$ Kvočka Trial Judgment, supra note 19, § 273.

${ }^{29}$ Ibid., § 284.

${ }^{30}$ Ibid., $\$ 306$.

31 Ibid., § 328.

32 Ibid., $§ 327$.

${ }^{33}$ Prosecutor v. Kvočka, Judgment, Case No. IT-98-30/1-A, ICTY Appeals Chamber, 28 February, 2005, § 90.
} 
furthering that JCE as a co-perpetrator. ${ }^{34}$ In Ojdanić, the Appeals Chamber states that JCE is a form of commission "insofar as a participant shares the purpose of the JCE (...) as opposed to merely knowing about it" and, therefore, "cannot be regarded as a mere aider and abettor (...)." ${ }^{35}$ This in turn means that if the participant only has knowledge, he can only be liable as an aider and abettor.

It follows from these considerations that the question of the correct form of participation is linked to the question of whether aiding and abetting a JCE is possible at all. While the Kvock a Trial Chamber takes this view, the Appeals Chamber only applies aiding and abetting to the single crime object of the complicity. While this restrictive view may be based on the wording of Art. 7 (1) ICTY Statute - since it makes a distinction between JCE, included in the term "committed", and "otherwise aided and abetted" - it is not necessary from a doctrinal perspective. On the contrary, as follows from the Kvock a Trial Chamber's concrete application and from the English law on common purpose, different forms of participation in a JCE are perfectly possible. The aider and abettor to a single crime committed within the framework of a JCE is still an aider and abettor to the JCE as such, except that this single crime is completely unrelated to the JCE. As to the difference between co-perpetration and aiding and abetting, the most convincing criteria are offered by the doctrine of the functional domination of the act (funktionelle Tatherrschaftslehre), widely recognized in civil law systems and recently also by the ICC's Pre-Trial Chamber. ${ }^{36}$ According to this theory, co-perpetration presupposes a functional cooperation of various persons (objective element) on the

\footnotetext{
${ }^{34}$ Ibid.; concurring Prosecutor v. Limaj et al., Judgment, Case No. IT-03-66-T, ICTY Trial Chamber, 30 November, 2005, § 510; Limaj et al. Appeals Judgment, supra note $9, \S \S 99$ et seq.; in favour of a subjective differentiation also: Cassese, supra note 6, at 116 .

${ }^{35}$ Prosecutor v. Ojdanić, Decision on Dragoljub Ojdanić Motion Challenging Jurisdiction- JCE, Case No. IT-99-37-AR72, ICTY Appeals Chamber, 21 May, 2003, § 20; Prosecutor v. Stakić, Judgment, Case No. IT-97-24-T, ICTY Trial Chamber, 31 July, 2003, § 432.

${ }^{36}$ Lubanga Confirmation of Charges, supra note $17, \S \S 322$ et seq. where the co-perpetration, on the basis of Art. 25 (3) (a) ICC Statute, is characterised as "joint control over the crime as a result of the essential contribution" (\$ 322), "coordinated individual contributions of a plurality of persons" (\$ 326) and, relying on the German theory of a "concept of control over the crime" (§ 338), as a "division of the essential tasks for the purpose of committing a crime between two or more persons acting in a concerted manner" (\$ 342). Confirmed by Katanga \& Ngudjolo Confirmation of Charges, supra note $17, \S \S 480$ et seq. (with regard to indirect perpetration or perpetration through another person).
} 
basis of a common plan or agreement (subjective element). ${ }^{37}$ If one follows this functional control concept, the requirements of co-perpetration are only fulfilled by JCE I, and only if it is construed as an objective-subjective structure, requiring, beyond the mere common purpose or will (subjective element), the actual performance of the act(s) by the member(s) of the enterprise (objective element). It seems as if the Tadić Appeals Chamber acknowledged this kind of identity between co-perpetration and JCE I, calling JCE I "co-perpetratorship",38 and comparing it to co-perpetration as invoked in the German and Italian post-World War II cases. ${ }^{39}$ It also seems that the ICTY/ICTR case law adopts the objective-subjective approach if it requires for JCE I that the participant "perform(s) (objective) acts that in some way are directed to the furthering of the (subjective) common plan or purpose". ${ }^{40}$ Thus, it seems correct to conclude that JCE I is a form of participation modeled on civil law co-perpetration ${ }^{41}$ and common law $^{42}$ common

${ }^{37}$ See for a detailed analysis: C. Roxin, Strafrecht. Allgemeiner Teil (2003), Vol. II, at 77 et seq.

38 Tadić Appeals Judgment, supra note 5, § 198. This terminology is settled; see recently: Prosecutor v. Babić, Judgment on Sentencing Appeals, Case No. IT-03-72, ICTY Appeals Chamber, 18 July, 2005, § 38.

39 Tadić Appeals Judgment, supra note 5, § 201; see also: Ibid., § 220 equating JCE I with co-perpetration.

${ }^{40}$ Ibid., § 229; Krnojelac Appeals Judgment, supra note 13, § 33; Vasiljević Appeals Judgment, supra note 13, § 102; Kvočka Appeals Judgment, supra note 33, § 89; Babić Appeals Judgment, supra note 38, § 38; Milutinović Trial Judgment, supra note $11, \S 103$.

${ }^{41}$ Cf. van Sliedregt, supra note 1, at 198-199. See also Stakić Trial Judgment, supra note $35, \S 439$. Against this background and the universal recognition of co-perpetration as a form of participation (see only Art. 25 [3] [a] 2nd alt. ICC Statute), it is more than surprising when the Appeals Chamber states that, on the one hand, "(T)his mode of liability (...) does not have support in customary international law (...)" but, on the other, JCE liability is "firmly established" (Stakic Appeals Judgment, supra note $13, \S 62$ ). This demonstrates such a blatant ignorance of basic principles of criminal law that even principled supporters of the International Criminal Tribunals, such as this writer, must rethink their support (critical also: H. Olásolo, "Reflections on the Treatment of the Notions of Control of the Crime and Joint Criminal Enterprise in the Stakic Appeals Judgment," [2007] 7 International Criminal Law Review [ICLR] 143, at 153-154.) In any case, the co-perpetration is explicitly recognised in Art. 25 (3) (a) ICC Statute, as was correctly held by the ICC Pre-Trial Chamber in Lubanga Confirmation of Charges, supra note 17, $\S 317$ et seq.

${ }^{42}$ While the Anglo-American Law on "complicity" requires a (causal) contribution of the accomplice, the JCE doctrine renounces this requirement and thus overcomes, from a prosecution perspective, this "defect" of the "normal" AngloAmerican law; see: van Sliedregt, supra note 1, at 196-197. 
purpose/design, i.e., it is a sui generis concept of ICL based on both common and civil law. ${ }^{43}$

The difficult issue is what (objective) acts are required for JCE I. The Kvočka Trial Chamber correctly says that the "precise threshold of participation in JCE has not been settled." 44 The famous ruling by the Tadic Appeals Chamber, adopted by most of the subsequent case law, according to which "participation" in the common design (read JCE) "may take the form of assistance in, or contribution to, the execution of the common plan or purpose," ${ }^{45}$ blurs the line between JCE I, understood as co-perpetration, and the other forms of JCE, especially JCE III. The Appeals Chamber's attempt to distinguish between co-perpetration and aiding and abetting fails since it only addresses, on the one hand, the relationship between principal (perpetrator) and aider and abettor, and, on the other, the subjective requirement of the agreement, leaving aside the difference between the objective contribution of the person acting on the basis of a common purpose (read: co-perpetrator) and the mere aider and abettor. ${ }^{46}$ In fact, if one takes the objective distinction of the Appeals Chamber seriously, an aider and abettor would do more than a co-perpetrator: the former carries out substantial acts "specifically directed" at assisting the perpetration of the (main) crime, while the latter must only perform acts (of any kind) that "in some way" are directed to the furthering of the common plan or purpose. ${ }^{47}$ This turns the traditional distinction between co-perpetration and aiding and abetting, i.e. the distinction with regard to the weight of the contribution, which must be more substantial in the case of co-perpetration, on its head. The only way to make sense of the argumentation of the Chamber would be to interpret the contribution of the accomplice member of a JCE as more important than that of the perpetrator (not part of the JCE) of the

\footnotetext{
${ }^{43}$ Van Sliedregt, supra note 1, at 202.

${ }^{44}$ Kvočka Trial Judgment, supra note 19, § 289.

45 Tadić Appeals Judgment, supra note 5, § 227; concurring: Krnojelac Appeals Judgment, supra note 13, 31 ; Vasiljević Appeals Judgment, supra note 13, § 100; Babić Appeals Judgment, supra note 38, § 38; Ntakirutimana Appeals Judgment, supra note 13, § 467; Martić Trial Judgment, supra note 8, § 440; Martić Appeals Judgment, supra note $8, \S 79$; Krajišnik Appeals Judgment, supra note 8, § 215.

${ }^{46}$ Cf. Tadić Appeals Judgment, supra note 5, § 229.

${ }^{47}$ Ibid., § 229; concurring: Krnojelac Appeals Judgment, supra note 13, § 33; Vasiljević Appeals Judgment, supra note 13, § 102; Kvočka Appeals Judgment, supra note $33, \S 89$.
} 
specific crime since the former contributed to the "risk" or "general danger" represented by the JCE as such. In other words, the importance of the contribution changes with the object of reference as an individual or a collective crime. Interestingly enough, the Vasiljević Appeals Chamber, albeit following the Tadic Appeal distinction, takes the view in the same paragraph that the participant in a JCE is liable as a co-perpetrator and as such incurs a higher degree of responsibility than an aider and abettor who, in any case, would always be an accessory to the co-perpetrators of a JCE. ${ }^{48}$ While this correctly describes the distinction between co-perpetration and complicity, it is imprecise with regard to the form of JCE - only JCE I constitutes, as a rule, co-perpetration and contradictory with regard to the Tadic Appeals Chamber's position which, as we have seen, attributes more weight to the contribution of the accomplice. Yet, one cannot have it both ways. Either JCE I is - in my view correctly - equated with co-perpetration and the corresponding rules apply, especially with regard to the delimitation of aiding and abetting, or the form of participation is left open at the level of attribution and differences are only, at best, taken into account at the sentencing level. ${ }^{49}$

\subsection{JCE II and III as Autonomous (Systemic) Concepts of Imputation}

In the light of these considerations, it is now possible to classify JCE II and JCE III. As to JCE III, it seems clear that its imputation of an act as a "foreseeable consequence" which was not agreed upon beforehand and consequently not intended by all participants can hardly constitute a form of co-perpetration or of perpetration at all if it is required, as explained above, that the perpetrator himself fulfill all objective and subjective elements of the offence. For in JCE III, one or more of these elements are missing and only imputed to the member of the enterprise by way of vicarious liability (responsabilité $d u$ fait d'autrui), i.e. by taking recourse to the act of another person, the actual perpetrator, transposing this act to the "non-actor" or "non-act" of that member. Yet, this non-act can only be considered

\footnotetext{
${ }^{48}$ Vasiljević Appeals Judgment, supra note 13, § 102.

${ }^{49}$ Prosecutor v. Kajelijeli, Judgment, Case No. ICTR-98-44A-T, ICTR Trial Chamber, 1 December, 2003, § 963; Vasiljević Appeals Judgment, supra note 13, 182; Babić Appeals Judgment, supra note 38, § 40; Milutinović Trial Judgment, supra note 11, § 106. Critical: Danner and Martinez, supra note 4, at 141-142.
} 
as a form of aiding and abetting to the crime in question. This is confirmed by traditional English doctrine which has long held that participants in a common criminal purpose are principals (only) in the second degree (i.e. accessories) in respect of every crime committed by any of them in the execution of that purpose. ${ }^{50}$

In the case of JCE II, the situation is more complicated and depends on the understanding of this category. If one characterizes JCE II as a "variant" or sub-category of JCE I ${ }^{51}$ with the same requirements, it can certainly be treated in the same manner. If, however, following the Kvocka Appeals Chamber, a "substantial contribution" to the enterprise is not necessary, but membership and foreseeability alone give rise to criminal responsibility, such a broad understanding of JCE II resembles rather JCE III ${ }^{52}$ than JCE I, and as such cannot be considered a co-perpetration. In this case, JCE II (in the broad sense) must structurally be classified, like JCE III, as a form of aiding and abetting a criminal enterprise and the additional question arises whether JCE II and III are encompassed by Art. 7 (1) ICTY/Art. 6 (1) ICTR Statute and Art. 25 (3) ICC Statute at all. As to Art. 7 (1) ICTY/Art. 6 (1) ICTR Statute, JCE II and III may only be subsumed under the "otherwise aided and abetted" formula if one construes the "otherwise" 53 as including any complicity in collective commission. Yet, aiding and abetting, as understood in the ICTY and ICTR Statutes and also Art. 25 (3) (c) ICC Statute, differs on the mental side from JCE II and III: it requires, on the one hand, knowledge ${ }^{54}$ or intent (within the meaning of Art. 30 ICC Statute) and, on the other, an act "for the purpose of facilitating the commission of such a crime." Thus, the only form of participation comparable to JCE II or III is the one of collective responsibility laid

${ }^{50}$ See: D. Ormerod, Smith \& Hogan Criminal Law (12th ed. 2008), at 182, quoting JF. Stephen, A Digest of the Criminal Law (9th ed. 1950), Arts. 37 and 38. See also: Ormerod, op. cit., at 206-208 (JCE as cases of secondary participation, parties to JCE as accessories).

51 Tadić Appeals Judgment, supra note 5, § 203, 228.

52 Consequently, Powles, supra note 25 , at 610 considers that for many of the so-called camp cases, the basis for liability is JCE III instead of II.

${ }^{53}$ Contrary to the Ojdanić Decision, supra note $35, \S 19$ the term "otherwise" does not suggest that the modes of liability set out in Art. 7 (1) are not exhaustive; correctly: Powles, supra note 25, at 611.

${ }^{54}$ See also: Powles, supra note 25, at 612-613 seeing an incompatibility of aiding and abetting and JCE III. 
down in Art. 25 (3) (d) ICC Statute. In fact, the Tadic Appeals Chamber considered that this form of responsibility contains a "substantially similar notion" and "upholds" the JCE doctrine, ${ }^{55}$ yet this view suffers from a lack of differentiation between the categories of JCE created by this very decision.

While JCE I constitutes, as shown above, a form of co-perpetration within the meaning of Art. 25 (3) (a) 2nd alt. ICC Statute, JCE II and III are not included in Art. 25 (3) (d) for at least two reasons. ${ }^{56}$ First, subparagraph ii of Art. 25 (3) (d) requires "knowledge" with regard to the criminal intent of the group, i.e. more than mere foreseeability as required by JCE II and III. ${ }^{57}$ Secondly, while one may argue that JCE II and III are covered by Art. 25 (3) (d) (i) since the voluntative element of this subparagraph ("aim of furthering the criminal activity [...]") is not incompatible with foreseeability, ${ }^{58}$ the contribution to the collective crime must, in any case, be "intentional" (Art. 25 [3] [d] 1st cl.), i.e., requires more than mere foreseeability. ${ }^{59}$ In addition, given the similarity between

${ }^{55}$ Tadić Appeals Judgment, supra note 5, § 222. For a general similarity also: K. Khan and R. Dixon, Archbold: International Criminal Courts: Practice, Procedure and Evidence (2nd ed. 2005), §§ 10-25; K. Kittichaisaree, International Criminal Law (2002), at 236 et seq.; W. Schabas, An Introduction to the ICC (3rd ed. 2007), at 212; J.D. Ohlin, "Three Conceptual Problems with the Doctrine of Joint Criminal Enterprise," (2007) 5 JICJ 69, at 85; Gustafson, supra note 6, at 158 (without further explanation); Cassese, supra note 6, at 132 .

${ }^{56}$ Critical also: Powles, supra note 25 , at $617-618$. For a different view: van Sliedregt, supra note 25, at 107-108.

${ }^{57}$ Cf. van Sliedregt, supra note 25, at 108. As to JCE II however, she argues that it can be brought under subparagraph (d) (ii) as to mid-level participants, if they had knowledge of the system of ill-treatment. See, however, her position in infra note 62 with main text.

${ }^{58}$ In this sense: Ohlin, supra note 55 , at 85 .

59 The counter argument of Cassese, supra note 6, at 132, demanding an extensive interpretation of the term "intentional" (requiring that "the intent be referred to the common criminal plan, and, as such, may also embrace acts performed by one of the participants outside that criminal plan ...") conflicts with the principle of legality, in particular with the prohibition of analogy provided for in Art. 22 (2) ICC Statute; the same applies to his interpretation of "knowledge" in Art. 25 (3) (d) (ii) extending it to a "foresight and voluntary taking of a risk." The contradiction between "intention" and "foreseeability" can only be resolved by distinguishing between the objects of reference of the intention required in Art. 25 (3) (d): while the concrete contribution of the participant to the collective act may well be intentional, she does not act intentionally with regard to the excesses, they only have to be "foreseeable" to her. 
responsibility based on JCE and conspiracy, ${ }^{60}$ the inclusion of the former in Art. 25 (3) (d) would, as stated above, conflict with the will of the drafters of the ICC Statute, who explicitly rejected conspiracy and drafted Art. 25 (3) (d) as a compromise formula. Against this background, Art. 25 (3) (d) can rightly be seen as a "statutory surrogate of JCE." 61 For the future case law of the ICC, this means that the application of JCE II (in the broad sense) and III on the basis of Art. 25 - and this is the only basis it has - is not possible. $^{62}$ This would ultimately mean introducing the law of conspiracy through the backdoor, ignoring the will of the drafters of the Rome treaty and violating the principle of legality. Only an explicit codification could reconcile JCE II and III with this principle's requirement for a, inter alia, strict and precise construction of criminal law provisions (Art. 22 [2] ICC Statute). ${ }^{63}$ All this leads to the conclusion that JCE II and III constitute autonomous (systemic) concepts of imputation without an explicit basis in codified ICL.

\subsection{Special Consideration: JCE III and the Principle of Culpability}

The principle of culpability or guilt has long been recognized in ICL. In general, the case law has recognized that the principle of (personal) guilt requires the Defendant's knowledge of the circumstances of the offence. The Nuremberg International Military Tribunal referred to the principle in the context of the question of criminal accountability of certain Nazi-organizations, stating that "one of the most important (legal principles)... is that criminal guilt is personal, and that mass punishments should be avoided" and that "the Tribunal should make such declaration of criminality (of an organization or group) so far as possible in a manner to ensure that innocent persons will not be punished." ${ }^{64}$ In the IMT's conception "personal guilt" meant that the accused would be individually responsible in objective and subjective terms and that no defense would negate his or her responsibility. In the subsequent trials, it was frequently repeated that individual

\footnotetext{
${ }^{60}$ Supra note 25 and main text.

${ }^{61}$ Fletcher and Ohlin, supra note 25, at 546, 549.

${ }^{62}$ In the same vein: van Sliedregt, supra note 25, at 354; for another view: Ohlin, supra note 55, at 78 et seq. who, however, proposes a restrictive interpretation with a view to the requirements of intention, foreseeability and culpability. For another view, in the result, see also the authors quoted in supra note 61 .

${ }^{63}$ See also: Stakić Trial Judgment, supra note 35, § 433.

${ }^{64}$ Trial of the Major War Criminals before the International Military Tribunal (The Blue Series), Vol. I, at 256.
} 
responsibility presupposes personal guilt. ${ }^{65}$ Similarly, the ICTY's Appeals Chamber recognized the principle of culpability in the Tadic case, stating that "nobody may be held criminally responsible for acts or transactions in which he has not personally engaged or in some other way participated (nulla poena sine culpa)." ${ }^{66}$ Although the principle is not explicitly contained in the ICC Statute, it clearly follows from the applicable law, either - in the light of the foregoing jurisprudence - as a principle and rule of international law within the meaning of Art. 21 (1) (b) of the Statute or as a general principle of law within the meaning of Art. 21 (1) (c) of the Statute. Under ECCC Law, the principle is recognized as part of the fair trial principle enshrined in Art. 33 new and as the other (substantive) side of the presumption of innocence (Art. 35 new [1]).

The conflict of JCE III with the principle of culpability is obvious. If, according to JCE III, all members of a criminal enterprise incur criminal responsibility even for criminal acts by some members which have not been agreed upon by all members before the actual commission but are, nonetheless, attributed to all of them on the basis of foreseeability, the previous agreement or plan of the participants as the basis of reciprocal attribution and, thus, a general principle in the law of co-perpetration is abolished. ${ }^{67}$ The existence of causality between the initial agreement or plan and the criminal excess does not overcome the deficit of culpability. ${ }^{68}$ In addition, the foreseeability

${ }^{65}$ U.S. v. Krauch \& Others, Trials of War Criminals before the Nuernberg Military Tribunals under Control Council Law No. 10 (The Green Series, hereinafter TWC), Vol. VIII, at 1081-1210, 1155-1156, 1157, 1158-1159, 1160; U.S. v. Krupp \& Others, TWC, Vol. IX, at 1327-1484, 1331, 1448; U.S. v. von Leeb \& Others, TWC, Vol. XI, at 462-697, 484. See also: U.S. v. Flick \& Others, TWC, Vol. VI, at 1187-1223, 1208 ("reasonable and practical standards" for the determination of guilt).

${ }^{66}$ Compare: Tadić Appeals Judgment, supra note 5, § 186 with further references. See also recently: Martić Appeals Judgment, supra note $8, \S 82$.

${ }^{67}$ See K. Ambos, Der Allgemeine Teil des Völkerstrafrechts (2nd ed. 2004), at 557 et seq.; id., supra note 3, at 174. See also: Martić Appeal Judgment, supra note 8, Separate Opinion of Judge Schomburg on the Individual Criminal Responsibility of Milan Martić, at 134, $§$ : “...the current shifting definition of the third category of JCE has all the potential of leading to a system, which would impute guilt solely by association".

${ }^{68}$ This is ignored by Cassese, supra note 6, at 119 when he argues that there is a "causal link between the concerted crime and the 'incidental" crime...". 
standard is neither precise nor reliable. ${ }^{69}$ Quite ironically, one may say that the foreseeability standard applied in this way makes the punishability for the accused unforeseeable. For this very reason - the insecurity of the foreseeability standard - one cannot blame the member of the JCE for not having withdrawn from the criminal enterprise: how and why should he do so if he does not even foresee the criminal result with certainty $?^{70}$ Ultimately, the doctrine introduces a form of strict liability with this standard. ${ }^{71}$ While this may just be the reason for the attractiveness of the doctrine for the prosecution, i.e., the possibility of elegantly overcoming the typical evidentiary problems in international criminal law crime scenarios, especially where proof of direct participation is lacking, ${ }^{72}$ it turns out to be its main disadvantage from the defense perspective.

Some of the judges also seem to have problems with the foreseeability standard. They either downgrade co-perpetration in a JCE to aiding and abetting (a JCE or a single crime) ${ }^{73}$ or try to increase or modify the subjective threshold by requiring knowledge together with foreseeability. According to the Appeals Chamber "this question must be assessed in relation to the knowledge of a particular accused." The prosecution must prove "that the accused had sufficient knowledge such that the additional crimes were a natural and foreseeable

${ }^{69} \mathrm{Cf}$. Fletcher and Ohlin, supra note 25 , at 550 . See also the examples given by V. Haan, "The development of the concept of joint criminal enterprise at the International Criminal Tribunal for the Former Yugoslavia", (2005) 5 ICLR 167, at 191-192.

${ }^{70}$ Crit. also Olásolo, supra note 41 , at $157-158$. For this reason Cassese's argument, (supra note 6 , at 120) that the culpability of the member of the JCE lies in the fact that he has not "prevented the further crime, or disassociated himself from its likely commission" is not convincing. In fact, it presupposes something (possible knowledge of the crime) which needs to be proved in the first place (this actual knowledge) and therefore is a classical petitio principii.

${ }^{71}$ See also: van Sliedregt, supra note 25, at 106 et seq., 357 et seq.; Schabas, supra note 53, at 216; G. Mettraux, International Crimes and the ad hoc Tribunals (2005), at 292-293; Haan, supra note 69, at 200; Fletcher and Ohlin, supra note 25, at 550. If this is true, it is not possible to construe a responsibility based on negligence as done by Ohlin, supra note 55 , at 83 .

${ }^{72}$ Cf. Vogel, supra note 1, at 421; Haan, supra note 69, at 172 et seq.; Danner and Martinez, supra note 4, at 134; van Sliedregt, supra note 1, at 187.

${ }^{73}$ See e.g. Prosecutor v. Blagojević, Judgment, Case No. IT-02-60-T, ICTY Trial Chamber, 17 January, 2005, $§ 704$ et seq., 713; Kvočka Trial Judgment, supra note $19, \S 273$ et seq. 
consequence to him.," ${ }^{, 74}$ While with knowledge more is required than with the Tadic dolus eventualis or recklessness standard, ${ }^{75}$ the linkage between knowledge and foreseeability is by no means clear. If one gives both standards a subjective meaning, i.e. referring to the mens rea of the concrete participant who shall be held responsible for the acts beyond the scope of the enterprise, the combination of them is like trying to square the circle. Either an accused knows that a certain result will occur or this result is foreseeable to him; both are logically impossible. In fact, knowledge is a standard for intent crimes (see Art. 30 ICC Statute), while foreseeability belongs to the theory of recklessness or negligence. The only way out of this impasse is to construe foreseeability as an objective requirement (in the sense of the notorious reasonable man standard) leaving the knowledge standard as the (only) subjective or mental requirement of liability. ${ }^{76}$ Obviously, this makes life for the defense more difficult, since it is easy for the prosecution and/or judge to allege that the "reasonable man" would have foreseen the criminal result and it is difficult, if not impossible, for the defense to rebut this affirmation. As a consequence, JCE III responsibility presupposes, firstly, the objective foreseeability of the crimes that went beyond the object of the enterprise (since normally such crimes occur in the ordinary course of events pursued by such an enterprise) and, secondly, the knowledge of the concrete participant with regard to this (objective) foreseeability. ${ }^{77}$ To put it more simply:

${ }^{74}$ Kvočka Appeals Judgment, supra note 33 , § 86; concurring: Limaj et al. Trial Judgment, supra note 34, § 512; Boskoski Trial Judgment, supra note 9, § 396.

${ }^{75}$ See supra after note 13 and main text: the accused (willingly) took that risk.

76 This view has been adopted by the Krajisnik Trial Judgment, supra note $6, \S$ 882. The same position is taken by Cassese, supra note 6 , at 123 , but with the argument (among others) that international crimes are normally committed in armed conflict and they are so serious that the foreseeability threshold must be lowered. Ohlin, supra note 55, at 81 conflates the objective and subjective if he requires foreseeability of the defendant, i.e., argues subjectively, and, in the next phrase, affirms that "if it is objectively foreseeable that other members of the enterprise might extend their actions beyond their agreement, then all members (...) can be charged with the crime".

${ }^{77}$ Although the case law is not clear, such an objective-subjective interpretation may be read into various statements requiring awareness with regard to possible (unintended) crimes, see e.g.: Prosecutor v. Brdanin \& Talić, Decision on Form of Further Amended Indictment and Prosecution Application to Amend, Case No. IT-99-36, ICTY Trial Chamber, 26 June, 2001, § 31; Prosecutor v. Blaskić, Judgment, Case No. IT-95-14, ICTY Appeals Chamber, 29 July, 2004, § 33. See also: Powles, supra note 25, at 609. More recently: Haradinaj Trial Judgment, supra note 14, § 139: "The objective element does not depend upon the accused's state of mind. This is the 
the participant must know that the crimes in question normally occur in the given enterprise. Yet, while this interpretation may make sense with regard to the otherwise illogical combination of knowledge and foreseeability and, in addition, may bring JCE III into line with the principle of culpability, it does not help in cases where the accused credibly pleads a lack of knowledge with regard to the foreseeability, i.e. argues that he - psychologically - was not aware of the - normatively construed - foreseeability of the excessive crimes. In this case, he would incur an error or mistake and the question would arise what type of mistake - of fact or law - would be applicable and what consequences this mistake would entail. Obviously, the recourse to the complex theory of mistake of law would not be necessary if one were to take into account the actual perception ex ante of the concrete accused instead of subjecting him to the reasonable man standard.

The opposite tendency is the expansion of the foreseeability standard to specific intent crimes and this is highly relevant with regard to genocide. The Brdanin Appeals Chamber ${ }^{78}$ downgraded the specific genocidal intent in the case of a JCE III to mere foreseeability, thereby bypassing the specific intent requirement and overcoming the well known evidentiary problems. The Miloševic Chamber merely followed this approach. ${ }^{79}$ Yet the approach is by no means settled in the case law. Unlike the Appeals Chamber, the Stakic and Brdanin Rule 98 Trial Chambers held that the specific (genocidal) intent must be met. ${ }^{80}$ In addition, in the posterior Krstić

\section{Footnote 77 continued}

requirement that the resulting crime was a natural and foreseeable consequence of the JCE's execution. It is to be distinguished from the subjective state of mind, namely that the accused was aware that the resulting crime was a possible consequence of the execution of the JCE, and participated with that awareness".

${ }^{78}$ Prosecutor v. Brdanin, Decision on interlocutory Appeals, Case No. IT-99-36-A, ICTY Appeals Chamber, 19 March, 2004, § 6.

${ }^{79}$ Prosecutur v. Milošević, Decision on Motion for Judgment of Acquittal, Case No. IT-02-54, ICTY Trial Chamber, 16 June, 2004, §§ 291 et seq.

${ }^{80}$ Stakić Trial Judgment, supra note 35, § 530; Prosecutor v. Brdanin, Decision on Motion for Acquittal pursuant to Rule 98bis, Case No. IT-99-36, ICTY Trial Chamber, 28 November, 2003, $\S 30$. In this sense also: Cassese, supra note 6, at 121, 133. See also, albeit not clear, the separate opinion of Judge Shahabuddeen to the Brdanin Appeals Decision, supra note 78, requiring, on the one hand, specific intent "always" (§ 4), but, on the other hand, stating that it is shown by JCE III (§5). For specific intent, also: doctrine, e.g. Mettraux, supra note 71, at 215, 264-265, 289; Haan, supra note 69, at 198-200; Danner and Martinez, supra note 4, at 151; van Sliedregt, supra note 1 , at 191 et seq. 
Appeal, JCE responsibility of the accused for the genocidal killings in Srebrenica was dismissed because of lacking a genocidal intent ${ }^{81}$ and JCE III was not invoked to overcome the mens rea problem.

\subsection{Intermediate Result}

The result from the above considerations can be summarized as follows:

(1) JCE I resembles traditional co-perpetration, since the participants act on the basis of a common plan ("common design" or "common enterprise"). If one construes JCE I as containing objective and subjective elements, in the sense of the functional control concept, it can be considered as a form of co-perpetration within the meaning of Art. 25 (3) (a) alt. 2 ICC Statute and as such as a form of commission pursuant to Art. 7 (1) ICTY/Art. 6 (1) ICTR Statutes.

(2) JCE II can be treated as a sub-category of JCE I if it is interpreted narrowly. In a broad sense of an extension of liability JCE II rather resembles JCE III and thus the following is applicable. ${ }^{82}$

(3) JCE III cannot be considered as a form of co-perpetration but only as a form of aiding and abetting the criminal enterprise. JCE II is an autonomous concept of imputation which does not constitute commission in the sense of Art. 7 (1) ICTY/Art. 6 (1) ICTR Statutes. In fact, JCE III demonstrates most clearly the JCE doctrine's similarity to classical conspiracy liability since it holds a participant in a criminal enterprise even responsible for the crimes of other participants not explicitly agreed upon beforehand provided that they are foreseeable. Thus, the liability is essentially based on the membership in the group pursuing the JCE and, as such, conflicts with the principle of culpability.

\section{APPLICATION BEFORE THE ECCC}

\subsection{The Test to be Applied: Legality as a Principle in ICL}

Art. 33 new (2) refers to Art. 15 ICCPR, and thereby makes the principle of legality (nullum crimen nulla poena sine lege) part of the ECCC's

${ }^{81}$ Prosecutor v. Krstić, Judgment, Case No. IT-98-33-A, ICTY Appeals Chamber, 19 April, 2004, §§ 134 et seq.; therefore, the Chamber convicted Krstic “only” for aiding and abetting genocide.

${ }^{82}$ On the disputed correct classification see also: V. Haan, supra note 27, at 200, 274 et seq. 
legal regime. Accordingly, "(N)o one shall be held guilty of any criminal offence on account of any act or omission which did not constitute a criminal offence, under national or international law, at the time when it was committed." (Art. 15 [1] ICCPR). For the crimes committed in Cambodia between 1975 and 1979, this means that they are only encompassed by the ECCC's jurisdiction if they constituted a (international or national) criminal offence at that moment in time. The principle of legality also applies to rules of imputation, as for example JCE, for these rules link the individual conduct to the crimes and as such must be considered as the basis for criminal responsibility.

While legality as a human rights principle, as enunciated by Art. 15 (1) ICCPR, appears to be limited to a prohibition of ex post facto criminalization, in modern $I C L$ the principle contains, on the basis of general principles of law and as its basic components, not only the lex praevia but also the lex certa rule. ${ }^{83}$ As to lex stricta, the situation is less clear. It may be considered as the equivalent of the rule of strict construction or interpretation, ${ }^{84}$ as developed in English law. ${ }^{85}$ Accordingly, judges are required to interpret the criminal law strictly, favoring the defendant in case of doubt. Yet, if one understands the lex stricta requirement only in the sense of the prohibition of analogy in malam partem, it is difficult to apply it in (traditional) common law jurisdictions, since there, the recourse to analogy is not prohibited, but must rather be seen as part of the discovery process of judicial law-making ${ }^{86}$ - as far as judicial law-making is still accepted (as in the legal systems of the United Kingdom). Art. 22 to 24 of the ICC

${ }^{83}$ See also A. Ashworth, Principles of Criminal Law (5th ed., 2006), 68: "governed by rules which are fixed, knowable, and certain"; also: A.P. Simester and G.R. Sullivan, Criminal Law. Theory and Doctrine (3rd ed., 2007), at 22. The lex certa rule in US law consists of the Void-for-Vagueness Doctrine of the U.S. Supreme Court, see W.R. LaFave, Criminal Law (4th ed., 2003), 103: "Undue vagueness in the statute will result in it being held unconstitutional, whether the uncertainty goes to the persons within the scope of the statute, the conduct which is forbidden, or the punishment which may be imposed (US v. Evans, 333 U.S. 483, 68 S.Ct. 634, 92 L.Ed 823 [1948])" (emphasis added).

${ }^{84}$ In this (broad) sense S. Dana, "Reflections on the ICC Sentencing Provisions and the Rights of the Accused in light of the Nulla Poena Principle", in A.H. Klip et al. (Eds.), Liber Amicorum et Amicarum voor Prof. mr. E. Prakken (2004), 351 at 352-353.

85 J. Hall, General Principles of Criminal Law (2nd ed., 1960), 38 et seq.; Ashworth, supra note 83 , at $80-82$.

${ }^{86}$ See R. Haveman, "The Principle of Legality", in R. Haveman et al. (Eds.), Supranational Criminal Law: A System Sui Generis (2003), 39 at 47-48 with further references. 
Statute go beyond these developments since they provide for a comprehensive concept of nullum crimen, including all four of its elements generally recognized in civil law jurisdictions: lex praevia, lex certa, lex stricta and lex scripta.

In any case, as to the case at hand, the gist of the issue is whether the application of JCE would violate the lex praevia rule, i.e., whether this form of liability existed at the time of commission in international or Cambodian criminal law at all. This test has been subdivided by the Milutinovic Appeals Chamber ${ }^{87}$ into three requirements which can, for our purpose, be reformulated as follows:

- JCE must have existed under customary international law at the relevant time (infra 4.3) or

- it must have been existed in national Cambodian law at the relevant time (4.4) and

- this form of liability must have been sufficiently accessible and foreseeable to the defendants at the relevant time (4.5).

The compliance with these requirements, however, does not suffice, since this liability must also be provided for by the applicable (ECCC) law. ${ }^{88}$ Indeed, this is the first question to be answered in the following.

\subsection{Is JCE Liability Provided for in the ECCC Law?}

The ECCC Law's short provision of individual criminal responsibility, Art. 29, states in its $\S 1$ that "(A)ny Suspect who planned, instigated, ordered, aided and abetted, or committed the crimes" within the jurisdiction of the ECCC "shall be individually responsible." This provision is identical to Art. 7 (1) ICTY and Art. 6 (1) ICTR Statutes. One may, therefore, first refer to the seminal Tadic Appeals Chamber's Judgment as to the interpretation of this provision, especially of the term committed. This judgment is, however, not completely clear as to whether participation in a crime by way of a JCE is encompassed by the term "committed" in Art. 7 (1) ICTY

\footnotetext{
${ }^{87}$ Prosecutor v. Milutinovic et al., Decision on Dragoljub Ojdanić's Motion Challenging Jurisdiction - JCE, Case No. IT-99 37, ICTY Appeals Chamber, 21 May, 2003, §§ 20-21. Concurring "Co-Prosecutors' Appeal of the Closing Order against Kaing Guek EAV 'Duch' dated 8 August, 2008”, Case File No. 002/19-092007-ECCC/OCIJ(PTC-02), 5 September, 2008, § 49.

${ }^{88}$ Milutinovic et al. Decision, supra note 87, § 21; Co-Prosecutors' Appeal, supra note $87, \S 49$.
} 
Statute. On the one hand, the Chamber acknowledges that "the commission of crimes (...) might also occur through participation in the realization of a common design or purpose" and Art. 7 (1) "does not exclude those modes of participating in the commission of crimes which occur where several persons having a common purpose embark on criminal activity that is then carried out either jointly or by some members of this plurality of persons." ${ }^{\prime 89}$ On the other hand, it states that the "Statute does not specify (either expressly or by implication) the objective and subjective elements (actus reus and mens rea) of this category of collective criminality." 90 The Statute only provides for an implicit basis $^{91}$ of collective participation in a crime in the sense of common design/purpose, somewhat puzzlingly called "a form of accomplice liability" by the Chamber. ${ }^{92}$ The specific elements of this liability, in the forms of JCE I, II and III, however, cannot be deduced from the Statute, but rather only from customary (case) law. The subsequent jurisprudence followed this view explicitly or at least in the sense that it regarded JCE as a form of commission in the sense of Art. 7 (1). ${ }^{93}$ The Co-Prosecutors' Appeals brief follows this view ${ }^{94}$ and complements it with a purpose based policy argument, namely that the ECCC's Law purpose to prosecute the "Senior Leaders of Democratic Kampuchea" and the "most responsible" can only be fulfilled if JCE is applied. ${ }^{95}$

This view is flawed for various reasons. First of all, it suffers from a lack of differentiation with regard to the three forms of JCE. While $J C E I$ resembles co-perpetration in a traditional sense and as such can be considered as "commission" within the meaning of Art. 7 (1) ICTY Statute, ${ }^{96}$ JCE III only entails accomplice liability and as such does not constitute commission. As to JCE II, it depends if it is

\footnotetext{
89 Tadić Appeals Judgment, supra note 5, §§ 188, 190.

90 Tadić Appeals Judgment, supra note 5, § 194.

${ }^{91}$ See explicitly: Tadić Appeals Judgment, supra note 5, § 220.

${ }^{92}$ Ibid.

${ }^{93}$ See: Krnojelac Appeals Judgment, supra note 13, § 29; Vasiljević Appeals Judgment, supra note 13, § 95; Blaškić Appeals Judgment, supra note 77, § 33; Milutinovic et al. Decision, supra note 87, § 20-21; Stakić Trial Judgment, supra note $35, \S \S 432,438$. Concurring with this extensive interpretation of Art. 7 (1): Cassese, supra note 6, at 114; critical Ohlin, supra note 55, at 71-72.

${ }^{94}$ Co-Prosecutors' Appeal, supra note 87, § 50.

95 Ibid., § 51.

${ }^{96}$ Cf. Powles, supra note 25, at 610-611; Haan, supra note 69, at 201. See also, albeit more radically: Prosecutor $v$. Simić, Separate and Partly Dissenting Opinion of
} 
understood rather in the sense of JCE I or JCE III (supra 3.6). Secondly, the Co-Prosecutors' brief does not only ignore these distinctions in its discussion of the ECCC law, ${ }^{97}$ but leaves the distinction between JCE I and III consciously open when it proposes to charge Duch in the alternative either as a co-perpetrator in a JCE (I) or for the crimes being a natural and foreseeable consequence of the criminal enterprise (JCE III). ${ }^{98}$ Third, the brief mixes policy arguments with a literal interpretation of Art. 29 ECCC Law apparently overlooking that the latter cannot be outplayed by the former. Finally, the Co-Prosecutors overlook that there is an alternative form of imputation for superiors, i.e., indirect perpetration based on the theory of control by way of a hierarchical organizational structure. While it would go beyond the scope of this brief to further analyze this theory, it is important to note that it has recently been recognized and explained by the ICC's Pre-Trial Chamber I ${ }^{99}$ and that it may also be applied before the ECCC, since it can be considered as a form of commission, namely a commission through another person (see explicitly Art. 25 [3] [a] alt. 3 ICC Statute). ${ }^{100}$

\subsection{Did JCE Liability Exist Under Customary (international) Law at the Relevant Time?}

The Tadic Appeals Chamber held the view "that the notion of common design as a form of accomplice liability is firmly established in customary international law." 101 The Co-Prosecutors' brief follows this view, yet, neither the Appeals Chamber nor the Co-Prosecutors

Footnote 96 continued

Judge Lindholm, Case No. IT-95-9/2, ICTY Trial Chamber, 17 October, 2003, $\S \S 2$ et seq. dissociating himself from JCE.

${ }^{97}$ Co-Prosecutors' Appeal, supra note 87, $\S \$ 49$ et seq.

98 Ibid., § 72, (d) vs. (e).

${ }^{99}$ Katanga \& Ngudjolo Confirmation of Charges, supra note $17, \S \S 480$ et seq. ("control over the crime approach"), especially footnotes 647, 678 and corresponding text.

${ }^{100}$ See: K. Ambos, "Art. 25. Individual criminal responsibility”, in O. Triffterer (Ed.), Commentary on the Rome Statute of the International Criminal Court (2nd ed. 2008), special print, marginal number (mn.) 20; id., "Command responsibility and Organisationsherrschaft", in A. Nollkaemper and H. van der Wilt (Eds.), System Criminality in International Law (2008), forthcoming.

101 Tadić Appeals Judgment, supra note 5, § 220. See also Martić Trial Judgment, supra note 8, § 435; Martić Appeals Judgment, supra note 8, $\S 80,81$; Rukundo Trial Judgment, supra note 14, § 23; Sesay Trial Judgment, supra note 15, § 255. 
take the differences between the distinct forms of JCE sufficiently into account. Also, Tadić's recourse to World War II case law is, at least in part, of "dubious precedential value." 102 Thus, if one takes a closer look at the case law analyzed by the Tadic Appeals Chamber, one reaches a twofold conclusion: while JCE I and II have a basis in customary law (i.e. post World War II case law), this is not the case for JCE III. ${ }^{103}$ From a strict logical perspective, this latter analysis is not necessary since JCE III is not encompassed, as demonstrated above (4.2), by Art. 29 (1) ECCC Law. However, for the sake of completeness, its customary status will also be analyzed as follows.

\subsubsection{JCE I}

Art. 6 last paragraph of the Statute of the Nuremberg International Military Tribunal and Art. 5 last paragraph of the Statute of the Tokyo Tribunal established a broad responsibility based on a common plan providing that "(L)eaders, organizers, instigators and accomplices participating in the formulation or execution of a common plan or conspiracy to commit any of the foregoing crimes are responsible for all acts performed by any persons in execution of such plan." Art. II (2) Control Council Law No. 10 establishes that a person has "committed" a crime when he "(d) was connected with plans or enterprises involving its commission or (e) was a member of any organization or group connected with the commission of any such crime." On this basis, the Nuremberg jurisprudence considered any form of participation - from mere consent to active conduct sufficient to be held responsible for the crime against peace, war crimes and crimes against humanity. In the Justice trial these criteria were applied such that Defendants who did not directly commit crimes were held accountable as accomplices because of a

${ }^{102}$ See: Ohlin, supra note 55, at 75. See also: Prosecutor v. Martić, supra note 8, Separate Opinion of Judge Schomburg on the Individual Criminal Responsibility of Milan Martić, Case No. IT-95-11-A, ICTY Appeals Chamber, 8 October, 2008, at $134, \S 4$ : “...nothing but an unsupported dictum."

${ }^{103}$ I rely here on previous works (supra note 67, Chapter 2 to 4 and "Individual criminal responsibility in International Criminal Law: A jurisprudential analysis From Nuremberg to The Hague" in G.K. McDonald and O. Swaak-Goldman [Eds.], Substantive and procedural aspects of International Criminal Law. The experience of international and national courts. Volume I. Commentary [2000], 1-31) and on a recent doctoral thesis written under my supervision: C. Barthe, Joint Criminal Enterprise. Ein (originär) völkerstrafrechtliches Haftungsmodell mit Zukunft? (2008), forthcoming. 
certain bureaucratic or functional involvement in crimes of the Nazi system. For the first time, a type of responsibility based on certain organizational functions within a bureaucratic apparatus was developed:

\begin{abstract}
"The charge (...) is that of conscious participation in a nationwide [sic!] governmentorganized system of cruelty and injustice, in violation of the laws of war and of humanity, perpetrated in the name of law by the authority of the Ministry of Justice, and through the instrumentality of the courts."104
\end{abstract}

Similarly, in U.S. v. Pohl \& Others participatory liability was based on the functional division of different tasks which, taken together, facilitate or promote the commission of the crime. The accused SS-members "operated and maintained the gigantic enterprises which resulted in the unlawful deaths of millions of slave laborers from occupied territories and prisoners of war." 105 In sum:

\begin{abstract}
"An elaborate and complex operation, such as the deportation and extermination of the Jews and the appropriation of all their property, is obviously a task for more than one man (...). As may be expected, we find the various participants in the program tossing the shuttlecock of responsibility from one to the other. The originator says: 'It is true that I thought of the program, but I did not carry it out.' The next in line says: 'I laid the plan out on paper and designated the modus operandi, but it was not my plan and I did not actually carry it out.' The third in line says: 'It is true I shot people, but I was merely carrying out orders from above.' The next in line says: 'It is true that I received the loot from this program and inventoried it and disposed of it, but I did not steal it nor kill the owners of it. I was only carrying out orders from a higher level.' To invoke a parallelism, let us assume that four men are charged with robbing a bank. (T) he acts of any of the four, within the scope of the overall plan, become the acts of all the others". ${ }^{106}$
\end{abstract}

In the famous trial of the Special Units (Einsatzgruppen) whose task was to "cleanse" the occupied territories in the East from "elements" considered racially and ethnically inferior by the Nazis, it was argued by Telford Taylor, Chief of Counsel of the Prosecution, that "those who take a consenting part in the commission of crime or are connected with plans or enterprises involved in its commission (...) and those who belong to an organization or group engaged in the commission of crime"

${ }^{104}$ U.S. v. Altstoetter \& Others, TWC, Vol. III, at 954-1201, 985. See also: United Nations War Crimes Commission, Law Reports of Trials of War Criminals, Vol. $\mathrm{XV}$, at 54 et seq. (hereinafter UNWCC Law Reports).

${ }^{105}$ U.S. v. Pohl \& Others, TWC, Vol. V, at 958-1163, at 1031 (emphasis added).

106 Ibid., at 1173 (supplemental judgment) (emphasis added). 
are responsible as "accessories." 107 The decisive fact is that the accused "were members of Einsatz units whose express mission, well known to all the members, was to carry out a large scale program of murder. Any member who assisted in enabling these units to function, knowing what was afoot, is guilty of the crimes committed by the unit."108

The argumentation of the Nuremberg tribunals concerning reciprocal attribution is reminiscent of the English doctrine of common design ${ }^{109}$ in that a plan or collective enterprise serves as the basis of attribution. The common design doctrine was applied in the British war crimes trials, as documented by the UNWCC. While as a general rule it was deemed sufficient that the Defendant was "concerned in the committing" of the crime, in the case of various participants, a reciprocal attribution of the individual contributions to the (main) offence was based on the participants having had a common purpose or plan within the meaning of the common design doctrine. A reciprocal attribution was also recognized in cases of a functional division of tasks between the accomplices. The most important case in this respect is the Almelo case where the Judge Advocate argued that the presence of the four accused in the killing of a prisoner of war (while "at the same time taking part in a common enterprise") was sufficient to hold all participants responsible for the killing since "each one in their [sic!] own way" assisted "the common purpose of all." 110 In other cases, liability was also based on the existence of a common purpose or plan ${ }^{111}$ and, in addition, on the "being

${ }^{107}$ U.S. v. Ohlendorf et al., TWC, Vol. IV, at 372 (emphasis added).
${ }^{108}$ Ibid., at 373 (with regard to the accused von Radetzky, Ruehl, Schuber and Graf).
${ }^{109}$ Cf. Ormerod, supra note 50, at 206-219.
${ }^{110}$ Trial of Otto Sandrock and three Others, British Military Court for the Trial of War Criminals held at Almelo, Holland (24-26 November, 1945), UNWCC Law Reports, Vol. I, at 40.

${ }^{111}$ Trial of Gustav Alfred Jepsen and Others, Proceedings of a War Crimes Trial held at Luneburg, Germany (13-23 August, 1946), Judgment of 24 August, 1946, at 241: "If JEPSEN was joining in this voluntary slaughter of eighty or so people, helping the others by doing his share of killing, the whole eighty odd deaths can be laid at his door and at the door of any single man who was in any way assisting in that act." Trial of Franz Schonfeld and others, British Military Court, Essen, (11-26 June, 1946), UNWCC Law Reports, Vol. XI, 64 at 68: "In our law, if several persons combine for an unlawful purpose or for a lawful purpose to be effected by unlawful means, and one of them, in carrying out the purpose, kills a man, it is murder in all who are present, whether they actually aid or abet or not, provided that the death was caused by a member of the party in the course of his endeavors to effect the common object of the assembly." (emphasis added). 
concerned" in the respective criminal offence. ${ }^{112}$ Thus, in sum, it can be concluded that JCE I liability was already recognized by the post World War II case law, and therefore, did also exist at the time of the commission of the crimes in question in Cambodia.

\subsubsection{JCE II}

As to the concentration camp cases covered by JCE II, the relevant case law has also been documented by the UNWCC. In the Dachau concentration camp trial, ${ }^{113}$ all accused were convicted on the basis of the concept of "acting in pursuance of a common design." 114 According to the Chief Prosecutor's closing argument "the test to be applied is not did he kill or beat or torture or starve, but did he, by his conduct, aid or abet the execution of this common design and participate in it?" 115 The Prosecution had to prove that (1) in Dachau existed a system for the mistreatment of prisoners or the commission of other crimes, (2) the respective accused knew of this system and (3) encouraged, aided and abetted or participated in the implementation of this system. ${ }^{116}$ If an accused only performed "neutral acts" in this system, i.e., the medical or service personnel, it had to be proved that this person abused his position to mistreat prisoners. ${ }^{117}$ In the Belsen

112 Trial of Robert Holzer et al., Canadian Military Court, Aurich, Germany, Record of Proceedings (25 March-6 April, 1946), Vol. I, Royal Canadian Air Force (RCAF) Binder 181.009, at 340; Trial of Valentin Feurstein and Others, Proceedings of a War Crimes Trial held at Hamburg, Germany (4-24 August, 1948), Judgment of 24 August, 1948, Original transcripts in Public Record Office, Kew, Richmond (England), summing up of the Judge Advocate 14th day (24 August, 1948), at 7: “(...) an accused, before he can be found guilty, must have been concerned in the offence. (...) [I]n other words, he must be the cog in the wheel of events leading up to the result which in fact occurred." (The mens rea required in this case, i.e. knowledge of the common purpose, was different from the one - "shared criminal intent" - in Tadić, see supra note 13 and main text); Trial of Max Wielen and 17 Others, British Military Court, Hamburg, Germany, (1 July-3 September, 1947), UNWCC Law Reports, Vol. XI, at 46: “(...) persons concerned must have been part of the machine doing some duty, carrying out some performance which went on directly to achieve the killing..." See also: UNWCC Law Reports, Vol. XV, at 49 et seq.; Ambos, supra note 67, at 142-143.

113 Trial of Martin Gottfried Weiss and thirty-nine others, General Military Government Court of the United States Zone, Dachau, Germany (15 November-13 December, 1945), UNWCC Law Reports, Vol. XI, 5-17.

114 Cf. UNWCC Law Reports, Vol. XV, at 94-95.

115 Dachau Trial, supra note 113, at 12 (emphasis added).

116 Ibid., at 13 .

117 Ibid. 
Trial, ${ }^{118}$ dealing with the crimes committed in the notorious concentration camps of Auschwitz and Bergen-Belsen, the Judge Advocate also relied on the concept of a "common concerted design" or "common agreement" to build his case against the accused:

"The case for the Prosecution (is) that all the accused employed on the staff at Auschwitz knew that a system and a course of conduct was in force, and that, in one way or another in furtherance of a common agreement to run the camp in a brutal way, all those people were taking part in that course of conduct. (...) the particular offender was acting willingly as a party in the furtherance of this system. (...) if the Court were satisfied that they were doing so, then they must, each and every one of them, assume responsibility for what happened. (...) throughout these camps the staff were made quite clearly to understand that the brutalities, ill-treatment, and matters of that kind would not be punished if they took place at the expense of the Jews; and that there was a common concerted design of the staff to do these terrible things." 119

In the Hadamar- ${ }^{120}$ and Velpke-Childrens' Home cases, ${ }^{121}$ the Courts had to deal with crimes committed by the accused as civilians in the exercise of their professions (for example as nurse). The basis of the reciprocal attribution of the respective acts of the accused again was apparently the collective system of mistreatment and abuses in which the accused consciously took part. As to Hadamar, the Prosecutor spoke of a "murder factory" where "you have to have several people doing different things (...) and you cannot draw a distinction between the man who may have initially conceived the idea of killing them and those who participated in the commission of those offences." 122 As a consequence, "there is no question (...) that any person, who participated in that matter, no matter to what extent, technically is guilty of the charge that has been brought (...). (E)very single one of the accused has overtly and affirmatively participated in this entire network that brought about the illegal results." 123

${ }^{118}$ Trial of Josef Kramer and 44 Others, British Military Court, Luneburg (17 September-17 November, 1945), UNWCC Law Reports, Vol. II, 1-156.

119 Ibid., at 120 (emphasis added).

${ }^{120}$ Trial of Alfons Klein and six others, United States Military Commission appointed by the Commanding General Western Military District, U.S.F.E.T., Wiesbaden, Germany (8-15 October, 1945), UNWCC Law Reports, Vol. I, 46-54.

${ }^{121}$ Trial of Heinrich Gerike and seven others, British Military Court, Brunswick (20 March-3 April, 1946), UNWCC Law Reports, Vol. VII, 76-81, quoted in: Kvočka Trial Judgment, supra note $19, \S 300$ et seq.

${ }^{122}$ Quoted according to A. Cassese, International Criminal Law (2nd ed. 2008), at 197.

123 Ibid. (emphasis added). 
Finally, the "common intent" or "common design" also served as the basis of attribution in the Flossenburg- ${ }^{124}$ and Mauthausen-Trials. ${ }^{125}$ According to the latter, ${ }^{126}$ the mere employment in a concentration camp or the mere presence entails a presumption of responsibility for war crimes. ${ }^{127}$ This, however, goes too far since it implies a reversal of the burden of proof as to the specific crimes. Indeed, the accused, being part of the organization of the camp, would have to refute the presumption by proving that he did not participate in the specific crimes. ${ }^{128}$ According to the UNWCC's comments ${ }^{129}$ on the Mauthausen trial, it contains two "findings of fact" and one legal conclusion. As to the former, it is said that the running of the Mauthausen concentration camp constituted a "criminal enterprise" and that everybody who worked in the camp or was merely present was aware of the "common design" and the criminal character of the enterprise. In legal terms, it is concluded that everybody who participated in this criminal enterprise is guilty of the violation of the laws and customs of war. In sum, three common elements to establish liability follow from the relevant case law:

${ }^{124}$ Trial of Friedrich Becker and others, United States Military Court, Dachau, Germany (14 May, 1946-22 January, 1947), quoted in UNWCC Law Reports, Vol. $\mathrm{XV}$, at 95 , footnote 1 .

${ }^{125}$ General Military Government Court of the U.S. Zone, Dachau, Germany (29 March-13 May, 1946), also called "Mauthausen Concentration Camp Case", quoted in the Dachau Trial, supra note 113, at 15.

${ }^{126}$ UNWCC Law Reports, Vol. XI, at 15.

${ }^{127}$ Ibid. See also the UNWCC comments on the Dachau-Trial, UNWCC Law Reports, Vol. XI, 15 et seq., as well as the Kvočka Trial Judgment, supra note 19, § 278.

${ }^{128}$ The German Supreme Court (Bundesgerichtshof) has, in the "Ausschwitz Concentration Camp Case" (in Justiz und NS-Verbrechen, Vol. XXI, at 838 et seq., 882), rejected such a broad liability arguing that it would even cover conduct which in no way encourages or supports the commission of specific crimes (also quoted in Tadić Appeals Judgment, supra note 5, § 203 fn. 254). See also the Kvočka Trial Judgment, supra note $19, \S 286$ : "The man who merely cleans the office afterhours and, however, sees the child photos and knows that the company is participating in criminal activity and who continues to clean the office, would not be considered a participant in the enterprise because his role is not deemed to be sufficiently significant in the enterprise." For a different, stricter view: F. Bauer, "Ideal-oder Realkonkurrenz bei nationalsozialistischen Verbrechen?", (1967) 22 Juristenzeitung 625 et seq.

${ }^{129}$ UNWCC comments on the Dachau-Trial, UNWCC Law Reports, Vol. XI, 15 et seq. 
- "there was a system in force to commit certain offences"

- "the accused was aware of the system" and

- "the accused participated in operating the system.".130

\subsubsection{JCE III}

While the above considerations show that JCE I and II have a basis in the post World War II case law, this is not the case with regard to JCE III. From the case law referred to by the Tadic Appeals Chamber, only the Essen Lynching case ${ }^{131}$ contains elements of the "common purpose" or "common design" doctrines insofar as the killings were attributed to all the accused on this basis (on their being concerned in the killing of the three unidentified British prisoners of war). Yet, it is not - inter alia because of the absence of conclusions by a Judge Advocate - clear whether the tribunal convicted the three accused on the basis of a shared intent with regard to the killing of the accused (i.e., pursuant to JCE I) or - as submitted by the Tadic Appeals Chamber ${ }^{132}$ - on the basis of the foreseeability doctrine, i.e. that it was foreseeable (objectively or subjectively) for all accused that the prisoners would be killed. In a similar vein, the Borkum Island Case, ${ }^{133}$ another case of mob violence, constitutes - on the basis of the case made by the Prosecution - proof of recourse to JCE I rather than JCE III. The Prosecution described the accused in this case as "cogs in the wheel of common design," each wheel on its own indispensable for the commission of the crime ("the wheel of wholesale murder could not turn without all the cogs.") Accordingly every person accused who "played his part in mob violence which led to the unlawful killing of the seven American flyers" had to be convicted of murder. ${ }^{134}$ Consequently, the Appeals Chamber itself concedes that this case

${ }^{130}$ UNWCC Law Reports, Vol. XV, 89 at 95. See especially: Dachau Trial, supra note 113 , at 13,15 .

${ }^{131}$ Trial of Erich Heyer and six others, British Military Court for the Trial of War Criminals, Essen (18-19 and 21-22 December, 1945), UNWCC Law Reports, Vol. I, at 88 .

132 Tadić Appeals Judgment, supra note 5, § 209.

${ }^{133}$ See for further information on the Borkum Island Case: Tadić Appeals Judgment, supra note 5, § 210-213.

${ }^{134}$ Compare Charge Sheet, U.S. National Archives Microfilm Publications, I, at 1190. 
could also be considered as a case of JCE I. ${ }^{135}$ Last but not least, the recognition of JCE III in customary law can not be deduced from the Italian case law quoted by the Appeals Chamber ${ }^{136}$ either, since in this trial - in contrast to the trials before British and U.S. American military tribunals - no international, but exclusively the national law (Art. 116 [1] of the Italian Codice Penale ${ }^{137}$ ) was applied. In addition, this case law is not uniform, since the Italian Supreme Court (Corte Suprema di Cassazione) has adopted two dissenting decisions. ${ }^{138}$

\subsection{Did JCE Liability exist in Cambodian National Law at the Relevant Time?}

The applicable criminal law at the relevant time is the Cambodian Penal Code of 1956. There is not yet a full translation of this Law into English or French, but an unofficial English translation was provided for this brief. This translation can be contrasted to two other sources available to the author.

According to the Commentary on the "Projet de Nouveau Code Penal", coordinated by Michel Bonnieu, traditional Cambodian law distinguished between dangerous and not dangerous perpetrators ("malfaiteur dangereux" and "non dangereux") and Art. 76 of the Codes of 1929 and 1955 (1956) defined the "auteur" (perpetrator) as the person who commits crimes ("infractions qu'ell commet..."). ${ }^{139}$ Co-perpetration was defined as "co-action" (coaction) in the Codes of 1929 and 1956, and its most important requirement was a common agreement between the co-perpetrators. ${ }^{140}$ Accordingly, by its wording, the provision did not encompass acts outside the agreement;

135 "It bears emphasizing that by taking the approach just summarized, the Prosecutor substantially propounded a doctrine of common purpose which presupposes that all the participants in the common purpose shared the same criminal intent, namely, to commit murder. In other words, the Prosecutor adhered to the doctrine of common purpose mentioned above with regard to the first category of cases." (emphasis added).

136 Tadić Appeals Judgment, supra note 5, § 214-219.

${ }^{137}$ On this provision see: F. Mantovani, Diritto penale (5th ed. 2007), at 523-527; A. Crespi, F. Stella and G. Zuccalà, Commentario breve al Codice Penale (8th ed. 2006), at 465-470.

138 Tadić Appeals Judgment, supra note 5, § 219 and fn. 277, 278.

${ }^{139}$ M. Bonnieu et al., Projet de Nouveau Code Penal. Commenté et comparé (2008), at 13 .

${ }^{140}$ Ibid., at 14 according to which the new Art. L. 1121-1122 requires a "commun accord". 
these could only be punished as complicity. ${ }^{141}$ In fact, according to the unofficial English translation, Art. 82 distinguishes between a direct and indirect participation and qualifies only the former as co-perpetration and the latter as complicity. According to Art. 87, aiding or abetting requires "assistance with full knowledge." An aider or abettor can only be considered a co-perpetrator "when he/she makes the offenses realized," i.e., when he/she him-/herself realizes the offence.

The Co-Prosecutors' Appeals Brief refers to Art. 82 and 145 of the 1956 Code stating that Art. 82 distinguishes between "co-action" and "complicity". Art. 145 provides for a definition of "co-authorship" referring to a plurality of persons who "confer or consult" with a view to the commission of a crime. An aider and abettor is considered an accomplice, not a co-author. Apart from the reference to Art. 145, which is not mentioned in any of the other available sources, the Appeals Brief correctly reproduces the applicable law at the time of commission. Given the influence of French Criminal Law in Cambodia, it is not surprising that the applicable French Code Pénal of the time (the Code Pénal of $1810,{ }^{142}$ Art. 59, 60), while it does not define different forms of perpetration, distinguishes between "auteur" (perpetrator) and "complice" (aider and abettor, accomplice) and thus confirms, at least, the model of participation followed by the Cambodian Code.

Thus, in sum, as to the recognition of JCE liability in Cambodian law at the relevant time, it follows that only JCE I existed unambiguously while JCE III was clearly not encompassed by the Code of 1956. As to JCE II, it depends if one construes it as a sub-category of JCE I or rather an extension of responsibility within the meaning of JCE III (see supra 3.6 no. 2).

\subsection{Was the Existing Liability Sufficiently Accessible and Foreseeable to the Defendants at the Relevant Time?}

Taking into account the above considerations, the answer to this final question is clear. First of all, only JCE I and II existed in customary international law at the relevant time. Thus, the question is, first, whether liability based on a common purpose, design or plan was sufficiently accessible and foreseeable to the defendants. The existence

\footnotetext{
${ }^{141}$ See the comment on Art. L. 1121-1125 in Ibid., at 15.

${ }^{142}$ Accessible at http://ledroitcriminel.free.fr/la_legislation_criminelle/anciens textes/code_penal_de_1810.htm (visited 20th October, 2008).
} 
of this liability not only in customary international law but also - as "co-authorship" - in the applicable Cambodian Penal Code demonstrates that this form of liability was accessible and foreseeable. Second, as to JCE II, it only existed as a sub-category of JCE I at the relevant time, and only insofar can be considered as sufficiently accessible and foreseeable. 